\title{
EMOTIONAL INTELLIGENCE, RELIGIOSITY, AND SOCIAL ATTITUDE OF STUDENTS
}

\author{
Rijal Firdaos \\ Universitas Islam Negeri (UIN) Raden Intan Bandar Lampung \\ Jl. Letnan Kolonel H. Endro Suratmin, Bandar Lampung, Indonesia, 35131 \\ Email: rijalfirdaos@radenintan.ac.id
}

Received; September 2016; accepted June 2017; published June 2017

\begin{abstract}
Students' low social attitude becomes one of the causes which can lead into immoral actions among students. The aim of this research is to acquire the relationship between emotional intelligence $\left(\mathrm{X}_{1}\right)$, religiosity $\left(\mathrm{X}_{2}\right)$, and social attitude of students $(\mathrm{Y})$. The method used in this research is a survey with an instrument of measurement using the questionnaire. The population in this research is 125 students in Islamic Education Department of Tarbiyah Faculty Semester VI in the 2015/2016 Academic Year. The number of samples are 60 students which were chosen by using multi-stage random sampling. The results of research show that there is a significant relationship between emotional intelligence $\left(\mathrm{X}_{1}\right)$ and social attitude of students $(\mathrm{Y})$, religiosity $\left(\mathrm{X}_{2}\right)$ and social attitude of students $(\mathrm{Y})$, and between emotional intelligence $\left(\mathrm{X}_{1}\right)$ and religiosity $\left(\mathrm{X}_{2}\right)$ with students' social attitude $(\mathrm{Y})$.
\end{abstract}

Keywords: Emotional Intelligence, Religiosity, Social Attitude.

\begin{abstract}
ABSTRAK
Rendabnya sikap sosial mahasiswa menjadi salah satu penyebab terjadinya tindakan amoral di kalangan mahasiswa. Penelitian ini bertujuan untuk. memperoleh hubungan antara kecerdasan emosional $\left(X_{1}\right)$, religiositas $\left(X_{2}\right)$, dengan sikap sosial mahasiswa (Y). Metode yang digunakan dalam penelitian ini adalab survei, dengan instrumen pengukuran menggunakan kuesioner. Populasi dalam penelitian ini adalah 125 mahasiswa Jurusan Pendidikan Agama Islam Fakultas Tarbiyah Semester VI tabun ajaran 2015/2016. Jumlah sampel sebanyak 60 mahasiswa yang dipilih dengan menggunakan multi stage random sampling. Hasil penelitian menujukkan terdapat bubungan yang signifikan antara kecerdasan emosional $\left(X_{1}\right)$ dengan sikap sosial mahasiswa $(Y)$, religiositas $\left(X_{2}\right)$ dengan sikap sosial mahasiswa $(Y)$, serta antara kecerdasan emosional $\left(X_{1}\right)$ dan religiositas $\left(X_{2}\right)$ dengan sikap sosial mahasiswa $(Y)$.
\end{abstract}

Kata Kunci: Kecerdasan Emosional, Religiositas, Sikap Sosial.

\section{INTRODUCTION}

Character education is an important part in educational world. The importance of character education is written in Indonesian Law No. 20 Year 2003 which states that the national education in Indonesia has the functions of developing the ability and forming the character and the Nation's prestigious civilization to make the Nation's life smart, to develop students' potency so as to become the human beings who are faithful and obedient to the Almighty God, having noble character, being healthy, educated, capable, creative, independent, and becoming democratic and responsible citizens. The national education is enforced from the early stage until the college stage. 
In colleges, the functions of education in character formation are emphasized in the Indonesian Law No.12 Year 2012 which states that the colleges have the functions in developing the ability and forming the character and the nation's prestigious civilization to make the nation's life smart, to develop innovative, responsive, creative, skillful, competitive, and cooperative academic activities through the enforcement of Tridharma and developing the science and the technology by considering and applying the value of humanity.

Character is also defined as attitude, disposition, or behavior. Attitude in humans is not formed by itself, but it is formed gradually as the life development goes on. According to Palok (1979, p. 97) in Psychological Dictionary, attitude is defined as a tendency to give the positive and negative responses to people, things, or certain situations. Attitude is also viewed as a filter in undergoing the life (Kebudayaan, 2001). Attitude in humans' life has a big role, for the attitude which is formed in humans will also determine the behavior in dealing with an object. One of the objects faced by humans is the values in society, so that they will form a social attitude.

Every human really needs formation of the good social attitude, and so do students. Students should be able to adapt themselves with social norms and values in society. Antisocial attitude is the cause and effect from the occurrence of deviate behavior. The deviate behavior makes human's psychological condition not in accordance with the valid norms. Criminal cases which spread now do not only prevail for commoners. As educated people, the students have become the subject from the criminal actions (Haryanti \& Firdaus, 2016). An incident of lecturer murder in the University of Muhamadiyah Sumatera Utara in May 2016 (Detik.com) is one of the examples from a student's negative attitude in responding to an incident.

Every student has different characteristics, likewise with emotional intelligence factor, and religiosity factor. Emotional intelligence gives the significant contribution to the entire fields both in intrapersonal life and interpersonal life. Some results of the old research show that the emotional intelligence has an influence toward teachers' productivity (Abidin, 2011) has a positive relationship with students' attitude toward, and has an influence toward the social attitude and study achievement (Iman, 2016). This article will present the results of research about the relationship between emotional intelligence, religiosity, and social attitude of students in Islamic Education Department of Tarbiyah Faculty Semester VI in the 2015/2015 Academic Year.

\section{METHOD}

The number of sample is 60 students which were chosen by using multi-stage random sampling. The method used in this research is a survey. Every research, either quantitative, qualitative or research development is not separated from instrument as the data collecting tool. The data collecting tools which are generally used such as questionnaire, test, interview, observation, and documentation really depend on the types of data which we need and the adaptability with the data analysis technique (Haryanti \& Firdaus, 2016). Data of emotional intelligence, religiosity, and social attitude of students in this research are collected by using the questionnaire instrument of the Likert scale model. The data are then processed to analyze the correlation between emotional intelligence, religiosity, and social attitude of students. To test the relationship between emotional intelligence, religiosity, and social attitude of students, the count of correlation coefficient is conducted by using product moment and test of regression. The test of correlation aims to seek how big the relationship and the contribution of two variables or more simultaneously (Riduan \& Sunarto, 2009, p. 86). While the doubled test of regression is used to estimate or predict the average of population based on the value of known independent variable (Ghozali, 2006, p. 81). 


\section{RESULTS AND DISCUSSION}

\section{Emotional intelligence}

Emotional intelligence is defined as the ability to identify, manage, and express precisely, including to motivate self, identify other people's emotion, and build the relationship with other people. To develop the ability of emotional intelligence, it can be started by identifying the emotion from self-awareness, managing the emotion, motivating oneself, understanding other people's emotion, and building the relationship (Hamachek, 2000, p. 235).

Emotional intelligence is popularized by Daniel Goleman in his famous book entitled Emotional Intelligence. He states that coordination of mood is the core of the good social relationship (Cobb \& Mayer, 2000). People have good emotional level if they are able to adapt with their environment and are able to adapt their mood with other individuals' mood (Cobb \& Mayer, 2000, p. 14).

Emotional intelligence is part of social intelligence involving the ability in understanding other people's emotion and restraining one's emotion and can be used as information in thinking and acting (Cobb \& Mayer, 2000, p. 14). Emotional intelligence is related to the feeling to recognize and appreciate one's feelings and others' feeling (Côté, 2014).

\section{Religiosity}

Religiosity has very big roles toward humans' ethical perception (Peterson \& Vanarragon, 2004). Religiosity, as spirituality, is defined as humans' awareness that their value, direction, and orientation are determined by their peaceful relationship with God (Sutrisno, 2005, p. 183). Religiosity is the relationship between human beings and the Highest, the Most Eternal, and the Most Singular One (Kasmahidayat, 2010, p. 27). Religiosity is also defined as the main potency or ability from humans' culture in deeply comprehending their lives based on conscience which is close to God. The humans who are provided with potency of spirituality in themselves can become the media of communication between themselves and their God and can also become reliable for other people's life in deeply comprehending and undergoing the life in the world.

Religiosity has big enough influences toward religious awareness (Amin, 2004, p. 9). Religious comprehension in recent era can no longer be approached and comprehended through only theological-normative approach. Warwanto (2009) says that education of religiosity is the faith communication between students in the same and different religions concerning their life experiences which dig the meanings, so that they are helped to be the intact humans (religious, having moral, open). Thereby, it is expected that they are able to become the doers of social changes for the sake of embodying the spiritual and material shared welfare.

Religion is an apocalypse which God sent to human beings. The basic functions of the religion are to give orientation, motivation, and help human beings identify and comprehend something sacral. Religious experiences are the comprehension of God, humans can have the capability, the ability and the sensitive feeling to identify and comprehend the existence of God (Mastuhu, 2003, p. 1). Awareness toward God's existence is an experience. Experience is a direct activity (Peterson \& Vanarragon, 2004, p. 137). The spiritual tendency and the height of humans' awareness are because humans trust these worldly realities. These realities are comprehensive and general, and have no economic advantages in them, and constitute the results of knowledge and comprehension concerning the world which the Prophets conveyed to human beings, or born by some philosophers' ideal thoughts (Muthahhari, 2008, p. 4). 


\section{Social Attitude}

Someone's social attitude principally can change in line with the surrounding objects and subjects. Students' ethical attitude can be affected by someone's emotional intelligence besides being affected by their spiritual intelligence (Cobb \& Mayer, 2000). Attitude is an important aspect because attitude of every individual can give color on the person's behavior and deeds. The human attitude is not formed by itself, but it is gradually patterned as the life development goes on (W. A., 1998).

The experts have explained about attitude. Gerungan $(1998, \underline{p}$. 150) states that attitude is more precise to be interpreted as willingness of reacting toward something. Another opinion is put forward by Wirawan (1996, p. 94) stating that the attitude is readiness of someone to act certainly toward the certain things. Mayor Palok (1979, p. 97) states that the attitude is a rather stabile tendency to behave or act certainly in certain situations. Thereby, attitude is someone's tendency toward a certain object or subject covering dimensions of cognition, affection, and connation. Attitude can be differentiated into social attitude and individual attitude. Social attitude is related to relationship between people and group or is related to people or group's influence with one another.

\section{Emotional Intelligence, Religiosity, and Social Attitude of Students in Islamic Education Department of Tarbiyah Faculty Semester VI in the 2015/2016 Academic Year}

To analyze the relationship between emotional intelligence, religiosity, and social attitude, data collection is conducted on 60 students in Islamic Education Department of Tarbiyah Faculty Semester VI in the 2015/2015 academic year. The data which are acquired on this research are the interval data. Data of emotional intelligence, religiosity, and social attitude are measured by using questionnaire of Likert scale model. The collected data about emotional intelligence in this research can be seen in Table 1.

Table 1. Data on Emotional Intelligence.

\begin{tabular}{ccccc}
\hline \multirow{2}{*}{ No } & \multirow{2}{*}{ Interval Class } & Absolute & \multicolumn{2}{c}{ Frequency } \\
\cline { 3 - 5 } & & Frequency & Relative (\%) & Cumulative (\%) \\
\hline 1 & $78-84$ & 3 & 5.00 & 5.00 \\
\hline 2 & $85-91$ & 9 & 15.00 & 20.00 \\
\hline 3 & $92-98$ & 17 & 28.33 & 48.33 \\
\hline 4 & $99-105$ & 16 & 26.66 & 74.99 \\
\hline 5 & $106-112$ & 8 & 13.33 & 88.32 \\
\hline 6 & $113-119$ & 6 & 10.00 & 98.32 \\
\hline 7 & $120-126$ & 1 & 1.66 & 10.00 \\
\hline & Total & 60 & 100.00 & \\
\hline
\end{tabular}

From the Table 1 above, there is one respondent (1.66\%) whose score is in the biggest interval; that is, $120-126$. There are three respondents $(5.00 \%)$ whose score is in the lowest interval; that is, $78-84$, while the majority of respondents, as many as 17 people $(28.33 \%)$ gain the score from 92 to 99 . In general, students' emotional intelligence in Islamic Education Department is categorized enough.

Data of religiosity gained from the results of this research can be seen in Table 2 .

Table2. Data of Religiosity.

\begin{tabular}{|c|c|c|c|c|}
\hline \multirow{2}{*}{ No } & \multirow{2}{*}{ Interval Class } & \multirow{2}{*}{$\begin{array}{l}\text { Absolute } \\
\text { Frequency }\end{array}$} & \multicolumn{2}{|c|}{ Frequency } \\
\hline & & & Relative $(\%)$ & Cumulative (\%) \\
\hline 1 & $118-123$ & 6 & 10.00 & 10.00 \\
\hline 2 & $124-129$ & 9 & 15.00 & 25.00 \\
\hline 3 & 130-135 & 19 & 31.66 & 56.66 \\
\hline 4 & 136-141 & 12 & 20.00 & 76.66 \\
\hline 5 & $142-147$ & 10 & 16.66 & 93.32 \\
\hline 6 & $148-153$ & 3 & 5.00 & 98.32 \\
\hline \multirow[t]{2}{*}{7} & 154-159 & 1 & 1.66 & 100.00 \\
\hline & Total & 60 & 100.00 & \\
\hline
\end{tabular}


The Table 2 states that there is one respondent (1.66\%) whose score is in the biggest interval; that is, $154-159$. There are six respondents $(10.00 \%)$ whose score is in the lowest interval; that is, from 118 to 123, while the majority of respondents as many as 19 people $(31.66 \%)$ gain score from 130 to 135 . In general, students' religiosity in Islamic Education Department is categorized enough.

Data of social attitude gained from the results of this research can be seen in Tale 3 below.

Table 3. Data of Social Attitude.

\begin{tabular}{ccccc}
\hline \multirow{2}{*}{ No } & \multirow{2}{*}{ Interval Class } & Absolute & \multicolumn{2}{c}{ Frequency } \\
\cline { 4 - 5 } & & Frequency & Relative (\%) & Cumulative (\%) \\
\hline 1 & $121-126$ & 3 & 5.00 & 5.00 \\
\hline 2 & $127-132$ & 4 & 6.66 & 11.66 \\
\hline 3 & $133-138$ & 5 & 8.33 & 19.99 \\
\hline 4 & $139-144$ & 16 & 26.66 & 46.65 \\
\hline 5 & $145-150$ & 19 & 31.66 & 78.31 \\
\hline 6 & $151-156$ & 10 & 16.66 & 94.97 \\
\hline 7 & $157-162$ & 3 & 5.00 & 100.00 \\
\hline & Total & 60 & 100.00 & \\
\hline
\end{tabular}

The Table 3 shows that there are three respondents (5.00\%) whose score is in the biggest interval; that is, $157-162$. There are three respondents $(5.00 \%)$ whose score is in the lowest interval; that is, from 121 to 126 , while the majority of respondents as many as 19 people $(31.66 \%)$ gain score from 145 to 150 . In general, students' social attitude from in Islamic Education Department is categorized good.

Test of Normality for Data of Emotional Intelligence, Religiosity, and Social Attitude of Students in Islamic Education Department of the Tarbiyah Faculty Semester VI in the 2015/2016 Academic Year

The data gained from the results of this research are then tested by normality test using chi square test. The test of normality aims to find out whether the taken samples derived from normal distribution or not (Arifin, 2012). If the data are distributed normally, then the parametric statistic will be used. On the contrary, if the data are not distributed normally, then nonparametric statistic will be used.

The process for the test of chi square on this research is helped by program of SPSS version 17.00. The hypothesis for normality testing is as follows:

$\mathrm{H}_{\mathrm{o}}$ : the data are derived from the population which follow the normal distribution.

$\mathrm{H}_{1}$ : the data are derived from the population which do not follow the normal distribution.

Normality count is conducted based on the significance of the asymp value:if the significance value of asymp is $<0.05$, then $\mathrm{H}_{\mathrm{o}}$ is rejected, and if the significance value of asymp is $>0.05$, then $\mathrm{H}_{\mathrm{o}}$ is accepted. The results of data normality count can be seen in Table 4 , showing that the data of emotional intelligence, religiosity, and social attitude have the value of significance $>0.05$. It means that $\mathrm{H}_{\mathrm{o}}$ which has been determined is accepted: that the data derived from the population are following the normal distribution.

Table 4. Summary for the Results of Data Normality Count.

\begin{tabular}{lccc}
\hline & $\begin{array}{c}\text { Emotional } \\
\text { Intelligence }\end{array}$ & Religiosity & Social Attitude \\
\hline Chi-Square a.b & 27.600 & 21.000 & 31.733 \\
df & 35 & 26 & 15 \\
Asymp. Sig & .809 & .742 & .007 \\
\hline
\end{tabular}




\section{The Relationship of Emotional Intelligence and Social Attitude of Students in Islamic Education Department of Tarbiyah Faculty Semester VI in the 2015/2016 Academic Year}

To test the relationship between emotional intelligence $\left(\mathrm{X}_{1}\right)$ and social attitude of students $(\mathrm{Y})$, the count of correlation coefficient is done by using product moment. The hypothesis which is determined is that, there is a positive relationship between emotional intelligence and social attitude of students. The hypothesis means that the higher the emotional intelligence is, the better the social attitude becomes. Statistically, the above hypothesis can be formulated as follows:

$$
\begin{aligned}
& \text { Ho }: \varrho_{\mathrm{y} 1}=0 \\
& \mathrm{H} 1: \varrho_{\mathrm{y} 1} \neq 0
\end{aligned}
$$

Table 5. Price of Correlation Coefficient.

\begin{tabular}{ccccc}
\hline Model & $\mathrm{R}$ & R Square & $\begin{array}{c}\text { Adjusted } \\
\text { R Sqauare }\end{array}$ & $\begin{array}{c}\text { Std. Error of } \\
\text { The Estimate }\end{array}$ \\
\hline 1 & $.684^{\mathrm{a}}$ & .468 & .458 & 9.319 \\
\hline
\end{tabular}

The counting by using the product moment gains the value of correlation coefficient of 0.684 as seen in the Table 5. The variables which are correlated are emotional intelligence $\left(\mathrm{X}_{1}\right)$ and social attitude of students $(\mathrm{Y})$. The value of correlation coefficient 0.684 shows that there is a strong influence of emotional intelligence toward students' social attitude.

Significance test of the simple correlation coefficient is then done by using t-test. The determination which is used is if it is $\mathrm{t}_{\text {count }}>\mathrm{t}_{\text {table }}$, then $\mathrm{H}_{\mathrm{o}}$ is rejected (significant correlation), and if it is $t_{\text {count }}<t_{\text {table, }}$, then $\mathrm{H}_{\mathrm{o}}$ is accepted (the correlation is not significant). The equation which is used is:

$$
\begin{aligned}
& \mathrm{t}_{\mathrm{h}}=\frac{\mathrm{r} \sqrt{ }\left(\mathrm{n}-{ }_{2}\right)}{\sqrt{ }\left(1-\mathrm{r}_{2}\right)}=\frac{0.684 \sqrt{ } 58}{\sqrt{ }(1-0.682)}=7.06 \\
& \mathrm{t}_{\mathrm{t}}=\mathrm{t}(0.05 ; 58)=1.67
\end{aligned}
$$

By using the above equation, the price of t-count which is gained is 7.06, while t-table for alpha is $5 \%$ and $\mathrm{dk} 58$ is 1.67. It means that the price of $\mathrm{t}{ }_{\text {count }}>\mathrm{t}$ table. The price of correlation coefficient 0.68 is significant and can be used for all populations. Thereby, the hypothesis stating that there is a positive relationship between the variables of emotional intelligence and social attitude of students has been tested for its validity. The results of research show that if students' emotional intelligence is increased, then their social attitude will be better.

The big contributions of the emotional intelligence variable toward students' social attitude can be seen from the value of determination coefficient or $R$ square $\left(R^{2}\right)$; that is 0.468 (it can be seen in Table 5). The point from the value of determination coefficient means that $46.8 \%$ variants of students' social attitude can be explained by the emotional intelligence.

The next step is doing an analysis of regression. The analysis of regression is meant to formulate the form of relationship equation between independent variable and dependent variable. General equation of the linear regression, $\hat{Y}=a+b X_{1}$, with $Y$ shows students'

\begin{tabular}{|c|c|c|c|c|c|}
\hline Model & & $\begin{array}{l}\text { redized } \\
\text { ients }\end{array}$ & $\begin{array}{l}\text { Standardized } \\
\text { Coefficients }\end{array}$ & & \\
\hline (Constant) & B & Std. Error & Beta & $\mathrm{T}$ & Sig. \\
\hline Emotional Intelligence & $\begin{array}{c}-19.795 \\
.882\end{array}$ & $\begin{array}{c}12.330 \\
.123\end{array}$ & .684 & $\begin{array}{c}-1.605 \\
7.138\end{array}$ & $\begin{array}{l}.114 \\
.000\end{array}$ \\
\hline
\end{tabular}
social attitude, $\mathrm{a}=$ constant, $\mathrm{b}=$ coefficient of regression, and $\mathrm{X}_{1}=$ emotional intelligence. The values of variable from the equation are shown in Table 6 below.

Table 6. Coefficient of Regression X1 
Table 6 shows the value of $\mathrm{a}=-19.795 ; \mathrm{b}=0.882$, so that the equation of linear regression is $\hat{\mathrm{Y}}=-19.795+0.882 \mathrm{X}_{1}$. The equation of linear regression can be defined if students' emotional intelligence increases one time, then their social attitude will go up 0.882 on constant -19.795 .

To think over whether the form of relationship on the sample can be used for all populations, it can be seen from the value of significance in the Table 6 , with determination if the value of significance is $<0.05$, then the form of relationship prevails for all populations. The data in the Table 6 show the value of significance $0.000<0.005$. The condition can be concluded that the relationship of emotional intelligence (X1) and social attitude $(\mathrm{Y})$ which is gained from the sample can be used for all populations.

The Relationship between Religiosity and Social Attitude of Students in Islamic Education Department of Tarbiyah Faculty Semester VI in the 2015/2016 Academic Year

The hypotheses which is determined to test the relationship between religiosity $\left(\mathrm{X}_{2}\right)$ and social attitude of students $(\mathrm{Y})$ is: there is positive relationship between religiosity and social attitude of students. The hypothesis means that the higher the religiosity is, the better the students' social attitude becomes. On the contrary, the lower the religiosity is, the lower the social attitude becomes. Statistically, the above hypothesis can be formulated as follows:

$\begin{array}{lll}\mathrm{H}_{0} & : \varrho_{\mathrm{y} 2} & =0 \\ \mathrm{H}_{1} & : \varrho_{\mathrm{y} 2} & \neq 0\end{array}$

Table 7. The Value of Correlation Coefficient for the Relationship between Religiosity and Social Attitude of Students

\begin{tabular}{ccccc}
\hline Model & $\mathrm{R}$ & R Square & $\begin{array}{c}\text { Adjusted } \\
\text { R Sqauare }\end{array}$ & $\begin{array}{c}\text { Std. Error of } \\
\text { The Estimate }\end{array}$ \\
\hline 1 & $.688^{\mathrm{a}}$ & .473 & .464 & 9.274 \\
\hline
\end{tabular}

The correlated data are the data of religiosity $\left(\mathrm{X}_{2}\right)$ and social attitude of students $(\mathrm{Y})$. The value of correlation coefficient which is acquired by the count result is 0.688 as seen in the Table 7.

The next step is doing a significance test of the simple correlation coefficient by using ttest. The count result appears on the equation below.

$$
\begin{aligned}
& \mathrm{t}_{\mathrm{h}}=\frac{\mathrm{r} \sqrt{ }\left(\mathrm{n}-\mathrm{-}_{2}\right)}{\sqrt{ }\left(1-\mathrm{r}_{2}\right)}=\frac{0.68 \sqrt{58}}{\sqrt{ }(1-0.682)}=7.06 \\
& \mathrm{t}_{\mathrm{t}}=\mathrm{t}(0.05 ; 58)=1.67
\end{aligned}
$$

The price of $t_{\text {count }}$ is 7.06 , while the price of $t_{\text {-table }}$ for alpha $5 \%$ and $\mathrm{dk} 58$ is 1.67 . It means that the price of $t_{\text {count }}>t_{\text {table, }}$, so that the price of correlation coefficient 0.68 is significant or can be used for all populations. Thereby, the hypothesis stating that there is positive relationship between variable of religiosity and social attitude of students has been tested for its validity. It means that if the religiosity is increased, then the students' social attitude will be better.

The big contribution of the variable of religiosity toward students' social attitude can be seen from the value of determination coefficient $\left(R\right.$ Square $/ R^{2}$ ), the value of which is 0.473 (Table 7). The value of determination coefficient means that $47.3 \%$ variants of students' social attitude can be explained by religiosity.

Then, to determine the equation of regression, based on the Table 8 , it gains a $=$ $75.201 ; \mathrm{b}=1.064$, so that the equation of linear regression is $\hat{\mathrm{Y}}=-75.201+1.064 \mathrm{X}_{2}$. 
The equation of linear regression means that if the religiosity increases one time, then the students' social attitude will go up 1.06 on the constant -75.201 . The equation of $\hat{Y}=$ $75.201+1.064 \mathrm{X}_{2}$ can be used for all populations based on the value of significance $0.000<$ 0.005 .

Table 9. Coefficient of Regression $\mathrm{X}_{2}$

\begin{tabular}{|c|c|c|c|c|c|}
\hline Model & $\begin{array}{r}\text { Unst } \\
\mathrm{Co} \\
\end{array}$ & $\begin{array}{l}\text { lardized } \\
\text { cients }\end{array}$ & $\begin{array}{c}\text { Standardized } \\
\text { Coefficients }\end{array}$ & & \\
\hline (Constant) & B & Std. Error & Beta & $\mathrm{t}$ & Sig. \\
\hline Religiosity & $\begin{array}{c}-75.201 \\
1.064\end{array}$ & $\begin{array}{c}19.863 \\
.148\end{array}$ & .688 & $\begin{array}{r}-3.786 \\
7.212\end{array}$ & $\begin{array}{l}.000 \\
.000\end{array}$ \\
\hline
\end{tabular}

The Relationship between Emotional Intelligence and Religiosity Simultaneously with Students' Social Attitude in Islamic Education Department of Tarbiyah Faculty Semester VI in the 2105/2016 Academic Year

The hypothesis which is determined to test the relationship between emotional intelligence $\left(\mathrm{X}_{1}\right)$ and religiosity $\left(\mathrm{X}_{2}\right)$ toward students' social attitude $(\mathrm{Y})$ is that, there is positive relationship between emotional intelligence and religiosity with students' social attitude simultaneously. The hypothesis means that the higher the students' emotional intelligence and religiosity simultaneously are, the better the students' social attitude is. On the contrary, the lower the students' emotional intelligence and religiosity simultaneously are, the worse the students' social attitude is. Statistically, the above hypothesis can be formulated as follows.

$\begin{array}{ll}\mathrm{H}_{0} & : \varrho_{\mathrm{y} 1.2}=0 \\ \mathrm{H}_{1} & : \varrho_{\mathrm{y} 1.2}>0\end{array}$

The correlated data are the data of variables of emotional intelligence $\left(\mathrm{X}_{1}\right)$ and religiosity $\left(\mathrm{X}_{2}\right)$ simultaneously with students' social attitude $(\mathrm{Y})$. The count result for the value of double correlation coefficient is 0.800 as seen in Table 10 .

Table 10. The Value of Correlation Coefficient for the Relationship between Emotional Intelligence and Religiosity Simultaneously with Students' Social Attitude

\begin{tabular}{ccccc}
\hline Model & $\mathrm{R}$ & R Square & $\begin{array}{c}\text { Adjusted } \\
\text { R Square }\end{array}$ & $\begin{array}{c}\text { Std. Error of } \\
\text { The Estimate }\end{array}$ \\
\hline 1 & $.800^{\mathrm{a}}$ & .640 & .627 & 7.735 \\
\hline
\end{tabular}

The double correlation coefficient 0.800 belongs to high category. The value of the double correlation coefficient which is gained is bigger than singular correlation between $\mathrm{X}_{1}$ and $\mathrm{Y}$, and between $\mathrm{X}_{2}$ and $\mathrm{Y}$. The double correlation coefficient 0.800 has just prevailed for the investigated sample.

To determine whether or not the correlation coefficient can prevail for population, the significance is tested with the following equation.

$\mathrm{F}_{\text {Count }}=\frac{\mathrm{R}^{2} / 2}{\left(1-\mathrm{R}^{2}\right) /(\mathrm{n}-3)}=\frac{0.640 / 2}{(1-0.640) / 57}=50.71$

$\mathrm{R} \quad$ : the double correlation coefficient which has been found.

$\mathrm{N}$ : total of sample member.

$\mathrm{F} \quad: \mathrm{F}_{\text {count }}$ which is then compared to $\mathrm{F}_{\text {table }}$

Price of $\mathrm{F}_{\text {count }}$ is then compared to $\mathrm{F}_{\text {table, }}$, with determination if it is $\mathrm{F}_{\text {count }}>\mathrm{F}_{\text {table }}$, then the tested double correlation coefficient is significant; that is, it can be used for all populations. Based on $\mathrm{dk}$ quantifier $=2$ and $\mathrm{dk}$ denominator $=57$, in level of error $5 \%$, it gains $\mathrm{F}$ table $=$ 
3.16, so that the price of $\mathrm{F}_{\text {count }}$ is $>\mathrm{F}_{\text {table }}(50.71>3.16)$. Thereby, it can be concluded that the double correlation coefficient which is gained on this research is significant or can be used on population where the sample is taken. This condition means that if the emotional intelligence and the religiosity are simultaneously increased, then the students' social attitude will be better.

The big contributions of the independent variable, emotional intelligence, and religiosity simultaneously toward students' social attitude can be seen in the Table 10 . The value of determination coefficient ( $R$ Square $/ R^{2}$ ) 0.640 means that $0.40 \%$ of variants of students' social attitude can be simultaneously explained by the emotional intelligence and the religiosity, while $36.0 \%$ is explained by another variable out of the two free variables.

To determine the double regression coefficient, then it can be seen on the count result as seen in the following Table 11.

Table 11. Significance Test Anova of the Double Regression Coefficient.

\begin{tabular}{rccccc}
\hline Model & $\begin{array}{c}\text { Sum of } \\
\text { Squares }\end{array}$ & df & Mean Square & F & Sig \\
\hline 1 Regression & 6051.494 & 2 & 3025.747 & 50.575 & $.000^{\mathrm{a}}$ \\
Residual & 3410.106 & 57 & 59.826 & & \\
Total & 9461.600 & 59 & & & \\
\hline
\end{tabular}

a. Predictors (Constant): Emotional Intelligence, Religiosity

b. Dependent Variable: Social Attitude

Table 11 shows the price of $\mathrm{F}_{\text {count }}=50.575$, while $\mathrm{f}_{\text {table }}$ for $\mathrm{dk}$ quantifier 2 and $\mathrm{dk}$ denominator 57 is $=3.16$. Thereby, the price of $\mathrm{F}_{\text {count }}>\mathrm{F}_{\text {table }}$ is $50.575>3.16$ which means that the double regression coefficient is significant.

The double regression is meant to determine the form of relationship equation from two independent variables and one independent variable. The double regression equation can predict the change of $\mathrm{Y}$ variable. To determine the influences of emotional intelligence and religiosity, the general equation $\hat{Y}=a+b_{1} X_{1}+b_{2} X_{2}$, with $Y=$ students' social attitude is used, $\mathrm{a}=$ constant, $\mathrm{b}_{1}=$ coefficient of emotional intelligence, $\mathrm{X}_{1}=$ emotional intelligence, $\mathrm{b}_{2}$ $=$ coefficient of religiosity, $\mathrm{X}_{2}=$ religiosity, which can be seen in Table 12 .

Table 12. The Value of Double Linear Regression Coefficient.

\begin{tabular}{|c|c|c|c|c|c|}
\hline Model & $\begin{array}{r}\text { Unstan } \\
\text { Coeff } \\
\end{array}$ & $\begin{array}{l}\text { rdized } \\
\text { lents }\end{array}$ & $\begin{array}{c}\text { Standardized } \\
\text { Coefficients }\end{array}$ & & \\
\hline (Constant) & B & $\begin{array}{l}\text { Std. } \\
\text { Error }\end{array}$ & Beta & $\mathrm{t}$ & Sig. \\
\hline Emotional & -89.201 & 16.790 & & -5.313 & .000 \\
\hline Intelligence & .597 & .116 & .463 & 5.136 & .000 \\
\hline Religiosity & .727 & .139 & .470 & 5.214 & .000 \\
\hline
\end{tabular}

a. Dependent Variable: Social Attitude

Table 12 shows that the result is $\mathrm{a}=-89.201 ; \mathrm{b}_{1}=0.597$ and $\mathrm{b}_{2}=0.727$, so that the double regression equation is $\hat{Y}=-89.201+0.597 \mathrm{X}_{1}+0.727 \mathrm{X}_{2}$. This means that if the emotional intelligence and the religiosity increase one time, then the students' social attitude will increase to 1.324 one time on the constant $-89,201$. The change of independent variable is significant toward the change of dependent variable, either individually or simultaneously. The condition is proved based on the significance of $\mathrm{X}_{1}$ and $\mathrm{X}_{2}$ with which has the value $0.00<$ 0.05 . 
Based on the above data, emotional intelligence is the ability of feeling, understanding, and effectively applying the energy and emotional sensitiveness as the sources of energy, emotion, connection, and human influence. Individual who is able to understand another individual's emotion can behave and make a decision precisely without bringing about the harmful impacts for both parties (Cobb \& Mayer, 2000). Religiosity is the quality of someone's comprehension of the life attitude based on religious values which they believe. The above statement indicates that someone's tendency in acting ideally has to refer to the strong religious bases in order to carry out the universal religious messages for life (Hakim, 2000). Both variables - or the emotional intelligence and the religiosity - have a role in forming someone's social attitude. Social attitude really depends on self-awareness which is formed by some internal and external factors. Among the internal factors, which can contribute positively toward development of the social attitude are the emotional intelligence and the religiosity.

The results of field data for the relationship between emotional intelligence, religiosity, and social attitude of students which have been analyzed can be explained as follows. The existence of relationship between emotional intelligence and social attitude of students can be explained that theoretically the emotional intelligence is the dominant predictor in determining the success of someone's life. Many results of research stating that: the emotional intelligence can determine someone's success in their occupation, either in works, career, or in education and process of learning. Emotional intelligence is defined as the ability to identify, manage, and express precisely, including motivate oneself, identify other people's emotion, and build the relationship with other people. It is obvious if an individual who has high emotional intelligence can live happier and more successful because of self-confidence and is able to restrain the emotion or has good mental health. Likewise with someone's social attitude, it covers honesty, responsibility, politeness, and working together, which if it all is possessed by every student will generate good personality.

Secondly, the results of research stating the existence of positive relationship between religiosity and social attitude of students can be explained that the religiosity is related to religious education. Religion is the effort to guide the human beings' lives following the orders of a religion. The religious adherents' lifestyle is based on their comprehension over the religious values which they adhere. Those values are absorbed to be practiced in daily life. Religious education has urgency in giving the constructive contributions for nation building. Even on personal rank, religion plays determinate roles in formation of children's character, morality, personality.

Religious education has important functions in developing students' disposition and personality. It also has a role in developing the system of the nation's healthy life, so that it can generate the generation who are responsible. In order that the education is able to meet these functions, the social attitude should always be developed in daily life, so that it can give stimulation to students toward religion.

Referring to Carr and Haldane in Taufik Parsiak, (2003, p. 156) religion is the social category and the empirical action. In this context, religion is formulated by being marked by three patterns of universal expression, namely: theoretical expression in the form of belief system, practical expression as system of worship, and sociological expression as system of social relation.

Essentially, religion is the rules from God Almighty in vertical and horizontal dimensions. It has functions in giving encouragement to the rational humans' soul by giving guidance according to God's rules over His own wish without any compulsion from other people. It means that if the religious human is obedient to carry out the entire religious teachings, then they live orderly in this world. This order life would ensure the security, 
tranquility, and peace in society, even the teenagers will be able to give positive contribution to society in the forms of security, tranquility, and peace. Thereby, someone's social attitude will be embedded well if it is supported by high values of religiosity because the social attitude which is affected by professional religious knowledge will generate the healthy personality both mentally and spiritually.

The above statement is supported by the result of research by Stavrova and Schlosser (2013), published in Why are Religious Happy? The Effect of the Social Norm of Religiosity Across Countries. In this research, the researchers take the respondents in 64 countries to test the level of happiness between religious people and those who have no religion. The result of research of Stavrova and Schlosser shows that the religious people live happier than those who have no religion. In addition, religion is very influential to someone's happiness if the country has the high religious social level.

Thirdly, the hypothesis stating that the relationship between the emotional intelligence and the religiosity simultaneously with students' social attitude can be explained that: the emotional intelligence demands an individuals to learn recognizing and appreciating their own feelings and other people's feeling; the religiosity as the quality of religious understandings based on the religious values they believe will affect consciously someone's social attitude. The emotional intelligence whose function is to manage self-awareness on someone's affective domain, and the religiosity which works to give a fortress on someone's spiritual domain, practically can give contributions toward someone's social attitude. It is because the religion commands the adherents to be able to plait the relationship vertically and horizontally. Both relationships can be actualized through deep comprehension toward the importance of the emotional intelligence and religiosity.

\section{CONCLUSION}

Results of the data analysis which are obtained from the field show the existence of relationship between the emotional intelligence and the religiosity with students' social attitude. The emotional intelligence and the students' social attitude correlate positively, and so do the religiosity and the social attitude. The positive correlation means that if the emotional intelligence or the religiosity goes up, then the students' social attitude will increase better. The emotional intelligence and the religiosity toward the students' social attitude simultaneously also correlate positively. Students' high emotional intelligence and religiosity will generate better social attitude. Students' low social attitude can be changed at least by two factors: emotional intelligence and religiosity.

\section{BLIBIOGRAPHY}

Abidin, Z. (2011). Filsafat manusia. Bandung: Rosda Karya.

Amin, A. (2004). Studi agama normativitas atau historisitas. Pustaka Pelajar.

Arifin, Z. (2012). Penelitian pendidikan metode dan paradigma baru. Bandung: Remaja Rosdakarya.

Cobb, C. D., \& Mayer, J. D. (2000). Emotional intelligence: what the research says. Educational Leadership, 58(3), 14-18.

Côté, S. (2014). Emotional intelligence in organizations. Annual Review of Organizational Psychology and Organizational Behavior, 1(1), 459-488. https://doi.org/10.1146/annurevorgpsych-031413-091233

Hakim, A. A. (2000). Metodologi studi islam. Remaja Rosdakarya.

Hamachek, D. (2000). Dynamics of self-understanding and self-knowledge: acquisition, advantages, and relation to emotional intelligence. The Journal of Humanistic Counseling, $38(4), 230$. 
Haryanti, E., \& Firdaus, F. (2016). Contribution of Indonesian democratic to islamic education. Jurnal Pendidikan Islam, 1(2), 165-182.

Kasmahidayat, Y. (2010). Agama dalam transformasi budaya nusantara. Bandung.

Kebudayaan, D. P. (2001). Kamus Besar Bahasa Indonesia. Jakarta: Balai Pustaka.

Mastuhu. (2003). Menata ulang pemikiran sistem pendidikan nasional abad 21. Yogyakarta: Insania Press.

Muthahhari, M. (2008). Manusia dan alama semesta. Lentera.

Palok, M. (1979). Sisologi suatu buku pengantar ringkas. Jakarta: PT. Ikhtiar.

Peterson, M. L., \& Vanarragon, R. J. (2004). Contemporary debates in philosophy of religion. Wiley.

Riduan, \& Sunarto. (2009). Pengantar statistika. Bandung: Alfabeta.

Sarwono, S. W. (1996). Pengantar umum psikologi. Jakarta: PT. Bulan Bintang.

Stavrova, O., Fetchenhauer, D., \& Schlösser, T. (2013). Why are religious people happy? The effect of the social norm of religiosity across countries. Social Science Research, 42(1), 90 105. https://doi.org/10.1016/j.ssresearch.2012.07.002

Sutrisno, M. (2005). Teks-teks kunci estetika, filsafat, seni. Jogjakarta.

Taufik Parsiak, T. (2003). Revolusi IQ/EQ/SQ. Bandung: Mizan.

W. A., G. (1998). Psikologi sosial. Bandung: Eresto.

Warwanto, H. J. (2009). Pendidikan sikap keberagamaan. Yogyakarta. 